WOJCIECH SZCZYGIELSKI

UNIWERSYTET ŁÓDZKI

\title{
Wokól ustawy o Sejmie z 12 maja 1791 r.
}

Na sesjach sejmowych w dniach 12 i 16 maja 1791 r. uchwalono bardzo ważną ustawę regulująca funkcjonowanie najwyższego organu ustrojowego państwa, tj. Sejmu1. Przyjmuje się, że decyzja sejmowa $z 12$ i 16 maja, mieszczaca się w nurcie ustawodawstwa wykonawczego wobec Ustawy Rządowej, była wyraźna koncesja na rzecz republikanizacji ustroju, stanowiąc swego rodzaju rewizję Konstytucji 3 maja $^{2}$.

$Z$ bardzo ostra krytyka ustawy sejmowej wystapił przed laty Władysław Smoleński, piszac: „Monarchizmowi ustawy rządowej reprezentanci narodu szlacheckiego wypowiedzieli walkę i zmogli go jednym zamachem w pierwszym akcie prawodawczym, jakim był opis sejmu z 12 i 16 maja. Przesączył się republikanizm szlachecki

1 Seymy, [w:] Volumina legum [dalej: Vol. leg.], t. IX, Kraków 1889, s. 250 i n. (obl. 28 V 1791). Por. też B. L e ś n o d o r s k i, Dzieło Sejmu Czteroletniego (17881792). Studium historyczno-prawne, Wrocław 1951, s. 245 i n., passim; Z. S z c z a s ka, Ustawa Rzadowa z 1791 r., [w:] Konstytucje Polski. Studia monograficzne $z$ dziejów polskiego konstytucjonalizmu, [t.] I, red. M. Kallas, Warszawa 1990, s. 58. Wagę ustawy podnosił marszałek Sejmu Stanisław Małachowski, mówiąc: „w podziale rządu jest najistotniejszym artykułem Sejm, bo ten najważniejszą władzę krajowa w sobie zawiera". Cyt. za: Dziennik Czynności Sejmu Głównego Ordynaryjnego Warszawskiego pod zwiazkiem Konfederacyi Obojga Narodów agitujacego się 1791, druk, sesja z $13 \mathrm{~V}$.

${ }^{2}$ Historia sejmu polskiego, t. I (Do schyłku szlacheckiej Rzeczypospolitej), red. J. Michalski, Warszawa 1984, s. 409-410 (rozdział autorstwa J. Michalskiego); Z. S zcząs ka, op. cit., s. 67; H. I z d e b s ki, Konstytucja Trzeciego Maja wśród konstytucji wieku Oświecenia, [w:] Konstytucja 3 maja. Prawo - polityka - symbol. Materiały $z$ sesji Polskiego Towarzystwa Historycznego na Zamku Królewskim $w$ Warszawie 6-7 maja 1991, red. A. Grześkowiak-Krwawicz, Warszawa 1992, s. 24. 
szczelinami, których konstruktorowie ustawy nie opatrzyli i budowę podmył niemal do gruntu”. Podkreślał, iż król i współautorzy Ustawy Rzadowej nie przeciwstawiali się tendencjom republikanizacyjnym, iż: „bronić własnego dzieła nie umieli i nie chcieli”. Była ustawa o Sejmie: „wyrazem [...] upodobań republikańskich” szlachty, jak ujmował to autor i przeciwstawiał ja monarchizmowi Ustawy Rzadowej. Jej przyjęcie przypisać należy, według Władysława Smoleńskiego, zwolennikom reformy postępującym w zgodzie $z$ zagorzałymi opozycjonistami. Nie wykreowała ustawy sejmowej opozycja trzeciomajowa, nie była to ustawa inspirowana intryga moskiewską ${ }^{3}$. Co się tyczy nowszej historiografii, to Bogusław Leśnodorski oceniał, iż prawo sejmowe było dziełem proreformatorsko zorientowanej zbiorowości parlamentarnej, podejmującej od zarania obrad wysiłki na rzecz uformowania nowego modelu państwa demokracji szlacheckiej4. Podstawowe konstatacje obu autorów dotyczace proreformatorskiego rodowodu i prokonstytucyjnych sympatii twórców nowego prawa sejmowego, pomimo różnic interpretacyjnych, nie budzą zastrzeżeń. Rzecz jednak w tym, iż rozważania te cechuje duży stopień uogólnienia problematyki, odnoszonej, w gruncie rzeczy, do anonimowo pojmowanej zbiorowości parlamentarnej ${ }^{5}$. W rozważaniach niniejszych pragnę więc przyjrzeć się bliżej uczestnikom debaty z 12 maja. Zwracam uwagę na potencjał polityczny popierających ustawę sejmową konstytucjonistów, na ich „barwę polityczna”; zarazem staram się ukazać, jaką rolę odegrała w debacie opozycja trzeciomajowa, akcentując zmienność jej zachowań. W opracowaniu niniejszym koncentruję się na zaprezentowaniu rezultatów głosowania, pomijajac kwestie związane $z$ dyskusja nad projektem ustawy.

Ustawa o Sejmie uchwalona została w dwóch częściach, na dwóch odrębnych sesjach parlamentarnych: 12 i 16 maja $1791 \mathrm{r}$., ale imienne głosowanie przeprowadzono tylko na pierwszej $z$ nich. $Z$ uwagi na fakt, iż druga część prawa o Sejmie w dniu 16 maja przyjęta została jednogłośnie, ograniczam niniejsze rozważania do sesji w dniu 12 maja, zadowalając się $z$ konieczności zestawem nazwisk parlamentarzystów, jakie figurują w zachowanym protokole

3 W. S moleń s ki, Ostatni rok Sejmu Wielkiego, Kraków 1897, s. 418-420 (por. też s. 26 i n.).

4 B. Le ś n o d o r ski, op. cit., s. 163-165, 298.

5 W. Smoleński (op. cit., s. 27-28) wymienia zaledwie kilka nazwisk uczestników debaty. 
głosowań z tego właśnie dnia6. Informacje personalne, pozyskane na podstawie owego protokołu głosowań konfrontuję $z$ ustaleniami Jana Dihma prezentujacymi pro- i antykonstytucyjne postawy parlamentarzystów - domniemanych uczestników sesji trzeciomajowej7, wspierając się dodatkowo na odrębnych jeszcze poszukiwaniach, majacych na celu ustalenie oblicza politycznego poszczególnych posłów i senatorów, nie uczestniczacych w debacie trzeciomajowej, a bioracych udział w sesji sejmowej z 12 maja ${ }^{8}$.

Projekt ustawy o Sejmie, który: „Deputacyja Konstytucyjna starała się [...] poprawić podług danego sobie od Stanów zalecenia stosowanie do teraźniejszej Konstytucyi rządowej”, wniesiony został pod obrady Izby na sesji z 9 maja9. Od zagajenia projektu o Sejmie rozpoczęła się sesja w dniu 10 maja, ale debatujacy nie otrzymali jeszcze wówczas ostatecznej jego wersji. Jak mówił marszałek Stanisław Małachowski projekt: „ten nie jest jeszcze całym [...] który niekoniecznie ma być decydowanym zaraz, aby Deputacyja uważać mogła zdania i wnioski o nim Najjaśn[iejszych] Stanów i do nich go stosować"10. I wreszcie na sesji w dniu 12 maja: „projekt ten poprawny"11, tj. poprawiony przez Deputację, stał się ostateczna podstawa do podjęcia decyzji ustawodawczej.

A więc na sesji z 12 maja przeprowadzono głosowanie nad propozycją: „Czyli projekt Sejmu w części pierwszej przeczytany i poprawiony ma być przyjęty? Czyli jeszcze do poprawy odesłany?"12

6 Protokół głosowań z 12 V 1791, Archiwum Główne Akt Dawnych w Warszawie [dalej: AGAD], Archiwum Sejmu Czteroletniego [dalej: ASC] nr 19, k. 157$157 \mathrm{v}, 158 \mathrm{v}-161,162-162 \mathrm{v}$. Przedstawione niżej wiadomości dotyczące sesji z $12 \mathrm{~V}$, o ile nie zostały zaopatrzone przypisem, zaczerpnięte zostały $z$ tegoż protokołu głosowań.

7 J. D i h m, Trzeci maj, Kraków 1932, s. 12, 16-20.

8 Zdaję sobie sprawę, że zaprezentowane w niniejszej publikacji wskaźniki liczbowe obarczone moga być pewnym błędem, wynikajacym $z$ dyskusyjności dokonanych kwalifikacji niektórych parlamentarzystów do grupy zwolenników czy przeciwników Konstytucji zarówno przez J. Dihma, jak i przeze mnie. Pamiętać musimy o tym, że stabilność postaw politycznych nie była najsilniejszą strona ówczesnych parlamentarzystów. Niemniej sytuacja ta, w swej ostateczności, nie przekładała się w jakiś istotniejszy sposób na zniekształcenie zaprezentowanych wskaźników liczbowych i w konsekwencji na osłabienie warstwy wnioskowej niniejszych rozważań.

9 Dziennik Czynności Sejmu... 1791, sesja z 9 V.

10 Ibidem, sesja z $10 \mathrm{~V}$.

11 Ibidem, sesja z $12 \mathrm{~V}$.

12 Protokół głosowań z 12 V 1791, AGAD, ASC nr 19, k. 157. Marszałek Sejmu Stanisław Małachowski, jak podaje inny diariusz, zgłosił propozycję w brzmieniu: 
Przeprowadzeniu głosowania sprzeciwiali się: Jacek Jezierski, kasztelan łukowski, Tadeusz Korsak, poseł wileński i Kazimierz Albin Skórkowski, poseł sandomierski, zgłaszając różnorakie obiekcje ${ }^{13}$. Ten ostatni, znany ze szczególnie drastycznej oceny Konstytucji 3 maja ${ }^{14}$, uchodził za najbardziej zdecydowanego przeciwnika Ustawy Rzadowej na pierwszych pokonstytucyjnych sesjach sejmowych ${ }^{15}$. Apelował, aby w trakcie trwającej sesji, projekt pierwszej części prawa o Sejmie: „mógł być [...] przyjęty”, król ${ }^{16}$. Marszałek wielki koronny Michał Mniszech oceniał, iż 3/4 obradujących parlamentarzystów skłania się ku przeprowadzeniu głosowania i w zwiazku z tym, jak uważał, należy je przeprowadzić17. I tak też postapiono. Zwolennicy nowego prawa sejmowego zwyciężyli stosunkiem głosów 111 do 7 . Za prawem o Sejmie opowiedziało się 90 posłów i 21 senatorów. Siedem głosów przeciwnych, to głosy poselskie ${ }^{18}$. Zwycię-

„Czyli projekt sejmowy w części pierwszej ma być przyjęty? [...] Czyli do Deputacyi dla poprawy odesłany”. Por. Dziennik Czynności Sejmu... 1791, sesja z 12 V.

13 Ibidem.

14 Diariusz Sejmu Wielkiego, AGAD, ASC nr 19, k. 216v, sesja z 17 V 1791 (oceniał to: „co się stało dnia 3 maja” za „zbrodnię”; mówił: „bezprawia w równości z prawem stawać nie zwykłem”); Dziennik Czynności Sejmu... 1791, sesja z $17 \mathrm{~V}$ („oświadczył, iż dzieło dnia 3 maja nie ma za dzieło godne Polaka [...] i nie lęka się bynajmniej za to kary w tym prawie wyrażonej”, stwierdzajac „bo ja Konstytucyja tę niewola narodu nazywam"). Por. też A. Grześkowiak-Krwawicz, Skórkowski (Sariusz Skórkowski) Albin Kazimierz, [w:] Polski słownik biograficzny [dalej: PSB], t. XXXVIII, Warszawa 1998, s. 348.

15 Pisano o nim: „W Izbie p. Skórkowski najżwawszy oponent, nieustannie powstaje na tę Konstytucyją" (Józef Rozan do Stanisława Szczęsnego Potockiego, Warszawa 18 V 1791, Biblioteka Czartoryskich w Krakowie - dalej: BCz, rkps 3473, s. 497). Por. też J.U. N i e m c e w i c z, Pamiętniki czasów moich, t. I, oprac. J. Dihm, [Warszawa] 1957, s. 342 („odjechał Suchorzewski, i Skórkowski, poseł sandomierski, zwolennik kanclerza Małachowskiego, na miejscu jego bruździć zaczał, mniej jednak skutecznie"). Por. też Stanisław August do Franciszka Bukatego, 14 V 1791, [w:] Ostatnie lata panowania Stanisława Augusta. Dokumenta do historyi drugiego i trzeciego podziału, wyd. W. Kalinka, Poznań 1868, s. 189 (Pamiętniki $z$ ośmnastego wieku, t. X, cz. II) - m.in. król mówił o nim: „Skórkowski antirewolucyjonista" - ibidem, s. 190.

16 Głos JKMci na sesji sejmowej dnia 12 maja 1791, AGAD, ASC nr 19, k. 156.

17 Diariusz Sejmu Wielkiego, AGAD, ASC nr 19, k. 150, sesja z 12 V 1791; Dziennik Czynności Sejmu... 1791, sesja z 12 V.

18 Obliczono na podstawie Protokołu głosowań z 12 V 1791, AGAD, ASC nr 19 , k. 157-157v, 158v-161, 162-162v. W diariuszach mylnie podano ogólną liczbę opowiadających się za ustawa posłów, jako 92 (Diariusz Sejmu Wielkiego, AGAD, ASC nr 19, sesja z 12 V 1791, k. 150v; Dziennik Czynności Sejmu... 1791, sesja z 12 V). Różnica ta, jak przyjmuje, wynikła z błędnego podliczenia danych 
stwo admiratorów nowego prawa sejmowego odniesione więc zostało ogromna, wprost przygniatająca, większościa ponad 100 głosów.

$Z$ analizy nazwisk opowiadających się po stronie ustawy sejmowej parlamentarzystów wynika, iż $88 \mathrm{z}$ nich to konstytucjoniści, 23 reprezentowało zaś formację malkontencką. Było więc nowe prawo sejmowe, w swej zasadniczej kanwie 88 oddanych głosów (75\% głosujacych) istotnie dziełem zwolenników Ustawy Rządowej. Jaki potencjał polityczny prezentowali parlamentarzyści składajacy się na owa grupę 88 posłów i senatorów? Otóż $68 \mathrm{z}$ nich $(58 \%$ głosujacych) to domniemani uczestnicy sesji trzeciomajowej optujacy na rzecz Ustawy Rządowej19. Obok nich grupę tę współtworzyło 20 głosujących, którzy nie uczestniczyli w sesji trzeciomajowej. Byli to jednak w większości zdeklarowani admiratorzy Ustawy Rzadowej czy po prostu parlamentarzyści zaangażowani w realizację procesu reformy w miesiącach bezpośrednio poprzedzających uchwalenie Konstytucji. Ich tożsamość ustalono w drodze odrębnego postępowania badawczego ${ }^{20}$. W grupie wspomnianych 88 parlamentarzystów znalazło się 56 sygnatariuszy Asekuracji Ustawy Rząowej z 2 maja $1791 \mathrm{r} .{ }^{21} \mathrm{~W}$ sumie można powiedzieć, że w gronie zwolenników ustawy sejmowej znaleźli się, w większości, najbardziej zasłużeni w kontekście przyjęcia Konstytucji majowej, parlamentarzyści. To oni właśnie byli właściwymi promotorami nowego prawa sejmowego, a kreowali je, w zasadniczym zrębie oddanych na nie głosów, uczestnicy sesji trzeciomajowej opowiadający się za Ustawa Rządowa. Oświeceni patrioci, reformując Sejm, wspie-

zamieszczonych w protokole głosowań. Głosy senatorów i liczba głosów przeciwnych - zgodna $z$ protokołem głosowan.

19 Obliczono na podstawie: J. Dih m, op. cit., s. 16-20; Protokół głosowań z 12 V 1791, AGAD, ASC nr 19, k. 157-157v, 158v-161, 162-162v.

$20 \mathrm{~W}$ grupie tej znaleźli się m.in. tak zdecydowani zwolennicy Konstytucji, jak: Antoni Gliszczyński i Antoni Kwilecki, posłowie poznańscy, Aleksander Zieliński, poseł nurski czy Adam Naruszewicz, biskup łucki. Ale do grona tego zaliczyłem też posłów, żywiących wobec Konstytucji 3 maja pewne zastrzeżenia. Np. Jan Nosarzewski, sędzic, poseł ciechanowski deklarował: „Jestem ja za tą Konstytucyja”; ale miał żal, jak mówił, iż: „gwałtownym sposobem Konstytucyja ta stanęła [...] nie wolnemi głosami, ale prawie przez gmin miasta zrobiona była". Cyt. za: Dziennik Czynności Sejmu... 1791, sesja z 13 V. Por. też M. Zł o m s k a, Nosarzewski Jan, [w:] PSB, t. XXIII, Wrocław 1978, s. 212.

21 Assekuracya, faksymile, [w:] B. D e m b iń s ki, Polska na przełomie, Warszawa 1913, po s. 486; Protokół głosowań z 12 V 1791, AGAD, ASC nr 19, k. 157$157 \mathrm{v}, 158 \mathrm{v}-161,162-162 \mathrm{v}$. 
rali się oczywiście na doświadczeniach wypływajacych $z$ republikańskiej przeszłości. Nie zamykali się jednak w hermetycznych ramach własnej tradycji; potrafili odwoływać się np. do wizji parlamentaryzmu angielskiego. Ludwik Gutakowski, poseł orszański, apelując o wydłużenie sesji sejmowych, mówił: „Weźmy wzór z sejmu angielskiego, jako najporządniejszego"22.

Zaprezentowana tu postawa szerokiego gremium prokonstytucyjnie zorientowanej zbiorowości szlacheckiej nie może dziwić. Ustawę o Sejmie należało by bowiem traktować jako końcowe, naturalne ogniwo w łańcuchu, który sięgał przedkonstytucyjnych uwarunkowań społeczno-politycznych zwiazanych $z$ powstawaniem Ustawy Rządowej. Pamiętać musimy o tym, iż przygotowanie i uchwalenie Konstytucji majowej dokonało się w wyniku wielkiego kompromisu politycznego zawartego pomiędzy szlachecka formacja parlamentarna, Puławami a królem, w sytuacji gdy inicjatywa konstytucyjna znalazła się w rękach Stanisława Augusta ${ }^{23}$, a jednocześnie w znaczącym stopniu wzrósł potencjał polityczny proreformatorsko zorientowanej zbiorowości szlacheckiej24. Nie wchodząc w szczegóły można powiedzieć, że ukształtowana wówczas formuła politycznego kompromisu reformatorskiego sprowadzała się do wypracowanej przez Ignacego Potockiego, króla i Stanisława Małachowskiego, wyrażajaccego interesy ugrupowania szlacheckiego, zasady, przewidujacej: „włączenie do konstytucji uzupełniających ja praw szczegółowych, które sejm ustanowi później"25. Można przyjąć, że ten właśnie „późniejszy”, a przewidziany w przedkonstytucyjnych uzgodnieniach termin uchwalenia owych praw szczegółowych przypadł właśnie na dzień 12 maja. Należy mieć na uwadze fakt, iż zgodnie z Deklaracja Stanów Zgromadzonych, uchwalona

22 Dziennik Czynności Sejmu... 1791, sesja z 16 V.

23 E. Ro s tw o row s ki, „Marzenie dobrego obywatela” czyli królewski projekt konstytucji, [w:] i d e m, Legendy i fakty XVIII w., Warszawa 1963, s. 354 i n. Tu też (s. 283 i n.) o projekcie konstytucyjnym króla.

${ }_{24}$ W. S z c z y gi e l s ki, Ze studiów nad postawami politycznymi posłów drugiej kadencji Sejmu Wielkiego w poczatkach 1791 roku, [w:] O prawie i jego dziejach ksieggi dwie. Studia ofiarowane profesorowi Adamowi Lityńskiemu $w$ czterdziestopięciolecie pracy naukowej i siedemdziesięciolecie urodzin, księga I, Białystok 2010, s. 544 i n.

25 Według: A. Grześkowi a k-Krwawi cz, Deklaracja Stanów Zgromadzonych z 5 czy z 3 maja 1791 roku?, „Kwartalnik Historyczny” 1992, R. XCIX, nr 1, s. 106. Por. też E. Ro s two row s ki, Marzenie dobrego obywatela..., s. 402403. 
prawdopodobnie 3 a nie 5 maja, jak dotychczas sadzono ${ }^{26}$, przyszłe ustawodawstwo okołokonstytucyjne, w tym oczywiście i ustawa o Sejmie, uznawane było wyprzedzająco „za część składająca tęż konstytucyja"27, a więc Ustawę Rządową. W odbiorze społecznym konstatowano, iż projekt ustawy o Sejmie: „do zapadłej na dniu 3 maja [Konstytucji - przyp. W.S.] usposobiony, Deputacyja podała Stanom do rozważenia i przyjęcia"28. Odnowiona i wyraźnie wzmocniona, od początków drugiej kadencji obrad sejmowych, szlachecka konfederacja sejmowa dopinała w szczegółach rozwiazania ustrojowe majace decydować o tym, aby kształtowany przez stan rycerski model państwa demokracji szlacheckiej istotnie zaspokajał oczekiwania ziemiańskiej szlachty.

W gronie konstytucjonistów zwolennikami ustawy o Sejmie byli parlamentarzyści wszystkich trzech konstruktywnie zorientowanych podmiotów politycznych, a więc uczestnicy szlacheckiej formacji parlamentarnej, ludzie dworu królewskiego i Puław. Ustawę, o której mowa, poparł przede wszystkim Stanisław Małachowski, marszałek Sejmu, faktyczny wyraziciel interesów szlacheckiej formacji parlamentarnej, stojący na straży szlachecko-republikańskiej tożsamości ustrojowej państwa. Opowiedzieli się po stronie nowego prawa sejmowego tak wybitni przedstawiciele owej formacji, a jednocześnie admiratorzy Ustawy Rzadowej, jak Stanisław Breza i Antoni Gliszczyński - posłowie poznańscy, Aleksander Linowski i Stanisław Sołtyk - posłowie krakowscy, Marcin Leżeński i Onufry Szczeniowski - posłowie bracławscy, Antoni Trębicki i Michał Zabiełło - posłowie inflanccy czy Aleksander Zieliński, poseł nurski. Ze strony zwolenników dworu królewskiego poparli nową ustawę sejmowa m.in. Tomasz Aleksandrowicz, wojewoda podlaski, Pius Kiciński i Onufry Oborski - posłowie liwscy, Franciszek Antoni Kwilecki, kasztelan kaliski i Adam Naruszewicz, biskup łucki. Puławian reprezentowali $\mathrm{w}$ tym gronie oczywiście Ignacy Potocki, marszałek wielki litewski, a również tak prominentni uczestnicy tegoż ugrupowania, jak ks. Adam Kazimierz Czartoryski, poseł lubelski, Julian Ursyn Niemcewicz, poseł inflancki, czy powiązany

26 A. Grze śkowiak-Krwaw ic z, Deklaracja Stanów Zgromadzonych..., s. $105-111$.

27 Deklaracya stanów zgromadzonych, [w:] Vol. leg., t. IX, s. 225 (obl. 5 V 1791).

28 Dominika Choynackiego Ś.P. Pamiętnik $z$ ostatnich lat panowania Stanisława Augusta, Biblioteka Kórnicka Polskiej Akademii Nauk [dalej: BK], rkps 927, k. 53 . 
z Puławianami, choć lubiący chadzać własnymi drogami Stanisław Kublicki, także poseł inflancki.

Natomiast stosunek opozycji trzeciomajowej do nowej ustawy o Sejmie przedstawia się w sposób nieco bardziej złożony. Antykonstytucjoniści głosowali w sposób niejednolity. 23 ich przedstawicieli, jak wspomniałem, poparło ustawę o Sejmie, 7 wyraziło wobec niej sprzeciw.

W wymienionej wyżej grupie 23 opozycjonistów popierających nowe prawo sejmowe znaleźli się domniemani uczestnicy sesji trzeciomajowej - przeciwni Konstytucji - w liczbie 1629. Do grupy tej zaliczyłem również 7 otwartych czy bardziej skrytych adwersarzy Ustawy Rzadowej, a więc tych, którzy uchodzili za zwolenników Rosji, parlamentarzystów znanych $z$ opozycyjnych bądź malkontenckich poglądów w okresie poprzedzającym uchwalenie Konstytucji. Dlaczego głosowali na rzecz przyjęcia ustawy sejmowej? Ocena motywów zachowania tej części uczestników obrad nie przedstawia się jednoznacznie. Można przypuszczać, iż po części kierowali się względami koniunkturalnymi, liczac na pozyskanie, tak czy inaczej pojmowanej, przychylności trzeciomajowego obozu zwycięzców. Zarazem charakter ustawy, akcentującej suwerenność Sejmu, powodował, iż mogła się ona wydawać bliska ich rzeczywistym poglądom.

Otwarty sprzeciw wobec nowego prawa o Sejmie wyraziło w głosowaniu jawnym zaledwie 7 posłów. Byli to Ignacy Chomiński, poseł oszmiański, Stanisław Jabłonowski, poseł nurski, Tadeusz Korsak, poseł wileński, Józef Kossakowski, poseł upicki, Ignacy Krzucki, poseł wołyński, Józef Pagowski, poseł inflancki i Michał Radzimiński, poseł czernihowski ${ }^{30}$. Jakie kierowały nimi motywy przy podejmowaniu owej decyzji? Niewatpliwie było to wielkie zacietrzewienie antykonstytucyjne. Na przykład jeden z nich, Stanisław

29 Obliczono na podstawie: J. Dih m, op. cit., s. 16-20; Protokół głosowań z 12 V 1791, AGAD, ASC nr 19, k. 157-157v, 158v-161, 162-162v. Kazimierz Nestor Sapieha, marszałek konfederacji litewskiej, figurujacy na listach J. Dihma jako opozycjonista (op. cit., s. 17), zakwalifikowany został, w niniejszych rozważaniach, do zwolenników Konstytucji.

30 Można tu zwrócić uwagę, że Tadeusz Korsak, początkowo przeciwnik Konstytucji 3 maja, pogodził się z nią. Por. B. Krakowski, Korsak Tadeusz, [w:] PSB, t. XIV, Wrocław 1968-1969, s. 116-117. Por. też W. S z c zygiels ki, Referendum trzeciomajowe. Sejmiki lutowe 1792 roku, Łódź 1994, s. 26, 297, 300-301. Sprzeciwiajacy się przeprowadzeniu głosowania Jacek Jezierski, kasztelan łukowski oraz Kazimierz A. Skórkowski, poseł sandomierski, nie wzięli udziału w głosowaniu. Por. Protokół głosowań z 12 V 1791, AGAD, ASC nr 19, k. 158v, 162 v. 
Jabłonowski, poseł nurski złożył w trakcie głosowania oświadczenie, tak mówiąc o Konstytucji 3 maja: „nie jestem za tym dziełem przez rewolucyja zrobionym i znam go być ze wszech miar nielegalnym i niedogodnym woli narodu i współbraci moich. Nie należałem do rewolucyi, nie chcę więc i do jej dzieła i szczegółów $z$ niego wynikajacych decyzyi, za tym dać mojej [zgody - przyp. W.S.] na ten projekt nie mogę" 31 . Wypowiedź ta zdaje się świadczyć, iż dla liderów opozycji trzeciomajowej linię postępowania w trakcie debaty wyznaczało kryterium polityczne, w postaci antykonstytucyjności, nie zaś względy merytoryczne zwiąane $z$ charakterem ustawy. Przesłanie powyższe, odzwierciedlające negatywny stosunek opozycji do nowego prawa sejmowego, stało się, jak można wnosić $z$ dalszego toku debaty, obowiąująca wytyczna postępowania malkontentów, jako zbiorowości parlamentarnej, dopiero w trakcie drugiego, tajnego głosowania.

I właśnie po głosowaniu jawnym, tego samego jeszcze dnia, nastapiło głosowanie tajne. Wyniki głosowania tajnego odbiegały poważnie od rezultatów głosowania wcześniejszego. W głosowaniu tajnym zwolennicy nowego prawa o Sejmie zwyciężyli stosunkiem głosów 90 do 2432. Przewaga popierajacych ustawę sejmowa zmalała ze 104 głosów w głosowaniu jawnym do 66 w głosowaniu tajnym.

Jest rzecza oczywista, że głosowanie tajne w sposób bardziej autentyczny odzwierciedliło faktyczne proporcje liczebne pomiędzy zwolennikami i przeciwnikami nowego prawa sejmowego. Znamienna zbieżność danych liczbowych w odniesieniu do głosowania jawnego i tajnego, pozwala przyjać, iż przemieszczenie głosów, do jakiego doszło $\mathrm{w}$ trakcie głosowania tajnego, wynikało przede wszystkim ze zmienności postaw parlamentarzystów o obliczu opozycyjnym, którzy w głosowaniu jawnym, w liczbie 23, poparli nowe prawo sejmowe. $Z$ dużą doza prawdopodobieństwa można przypuszczać, że grupa parlamentarzystów o poglądach opozycyjnych, uczestniczaca w debacie z 12 maja, a liczaca w sumie, jak podano wyżej, 30 osób, pomniejszona została o czterech posłów rezygnujacych $\mathrm{z}$ udziału $\mathrm{w}$ głosowaniu tajnym i o dwóch, którzy zasilili szeregi zwolenników nowego prawa sejmowego. Wydaje się, że w ostatecznej rozgrywce parlamentarnej, a więc $\mathrm{w}$ trakcie głosowania tajne-

31 Diariusz Sejmu Wielkiego, sesja z 12 V 1791, AGAD, ASC nr 19, k. 150150v.

32 Ibidem, k. 151; Dziennik Czynności Sejmu... 1791, sesja z 12 V. Por. też W. S moleń ski, op. cit., s. 419; B. Le śn od or ski, op. cit., s. 165. 
go, kryterium czysto polityczne, o zabarwieniu antykonstytucyjnym, stawało się bezwzględnym priorytetem określającym tok postępowania ustawodawczego opozycji. Głosowanie tajne dało wyraz rzeczywistego odniesienia się ugrupowania opozycyjnego do nowej ustawy sejmowej. Stanowiło przejaw zdyscyplinowania politycznego szeregów opozycji, w wyniku czego potrafiła ona skupić nieco powyżej 20\% głosów uczestniczacych w debacie parlamentarzystów.

Opozycjoniści, choć zjednoczeni, uzyskali w głosowaniu tajnym zaledwie $21 \%$ głosów ogółu obradujących, ponosząc dotkliwa porażkę. Był to bodaj najniższy wskaźnik głosów osiagnięty przez opozycję w ważnych politycznie debatach na przestrzeni ostatnich kilku miesięcy ${ }^{33}$. Po sesji trzeciomajowej wielu opozycjonistów, zszokowanych jej przebiegiem i rezultatami wycofało się po prostu $z$ obrad parlamentarnych, oddając niejako pole działalności sejmowej konstytucjonistom. $Z$ obozu malkontentów płynęły wiadomości typu: „Znaczna liczba nieukontentowanych posłów, albo wyjechała, albo w Warszawie bawiąc, nie bywaja na sesyjach, stąd wynika, że sesyje sejmowe spokojnie się odbywają. Zdaje się, że jedni ręce opuszczali, nie widzac sposobu odmienienia lub poprawienia rzeczy, drudzy się oddalają, aby się nie kompromitowali" 34 . Najbardziej zdeklarowani opozycjoniści zdystansowali się od obrad sejmowych. Jan Suchorzewski, poseł kaliski, opuścił Warszawę35, Benedykt Hulewicz, poseł wołyński, przebywając w stolicy, bojkotowal debaty parlamentarne ${ }^{36}$.

Stanisław Małachowski konstatował przyjęcie pierwszej części prawa o Sejmie, piszac: „Projekt Sejmu przedsięwzięto, który w niejakich artykułach już przyjęty a w innych do deliberacyi poszedł”37.

$33 \mathrm{~Np}$. w początkach stycznia $1791 \mathrm{r}$. opozycjoniści, choć w oczywistej mniejszości, potrafili jednak zgromadzić $1 / 3$ ogółu głosów (W. Szczygielski, Ze studiów nad postawami politycznymi posłów..., s. 544); a w trakcie sesji trzeciomajowej $-40 \%$ ( $z$ danych J. D i h m a, op. cit., s. 16-20).

34 Józef Rozan do S.S. Potockiego, Warszawa 25 V 1791, BCz, rkps 3473, s. 575 .

35 J. N i e m c e wi c z, op. cit., t. I, s. 342.

36 Benedykt Hulewicz do S.S. Potockiego, Warszawa 14 V 1791, BCz, rkps 3473, s. 475 („Ja na sesyjach nie bywam wcale”). Por. też Stanisław Małachowski do S.S. Potockiego, Warszawa 25 V 1791, BCz, rkps 3473, s. 507-508 („JW. Hulewicz chociaż tu przytomny, postanowił nie bywać na sesyjach"). Istotnie nie uczestniczył w głosowaniu na sesji z 12 V (Protokół głosowań z 12 V 1791, AGAD, ASC nr 19, k. 159v).

37 Stanisław Małachowski do S.S. Potockiego, Warszawa 14 V 1791, BCz, rkps 3473, s. 479. 
Ignacy Potocki w dzień po przyjęciu pierwszej części prawa o Sejmie, tak pisał ogólnie o pokonstytucyjnym ustawodawstwie do Szczęsnego Potockiego: „Szczegóły, które ustawy nasze rządowi objaśnią bardziej jeszcze zniszczą zarzuty jakie $z$ pierwszego czytania na dzisiejsza miotaja się Konstytucyja" 38 . Kontekst czasowy wypowiedzi, skierowanej do określonego adresata, pozwala przyjać, iż widział Ignacy Potocki nowe prawo sejmowe w ramach pokonstytucyjnego ustawodawstwa „objaśniajacego" Ustawe Rzadowa, a zmierzającego do republikanizacji ustroju państwa. Król tak oceniał przyjęcie pierwszej części ustawy o Sejmie: „Zreszta przeformowano cała pierwsza połowę seksternu rządowego pod tytułem sejm, stosownie do aktu rewolucyi, turnusem nawet sekretnym stu przeciwko dwudziestu"39. Oceniał też, że druga część prawa (uchwalona 16 maja) wymagać będzie poważnego wysiłku legislacyjnego. Pisał więc: „Na sesyi wczorajszej przeczytano tylko druga połowę tegoż urządzenia sejmowego. Przez dziś i jutro, trzeba będzie tę druga połowę zupełnie przeformować, bo jest wydrukowana przed rewolucyja i wcale $z$ nią nie zgodna" 40 . W nieco spóźnionej informacji prasowej, czytamy: „Już pierwsza część o Sejmach jest udecydowana pluralitate, a druga pod decyzyję wychodzi i pewno pluralitate załatwi się"41.

Natomiast na sesji w dniu 16 maja druga część prawa o Sejmie przyjęta została jednogłośnie ${ }^{42}$ i nie wiemy w jakiej liczbie uczestniczyła opozycja w tej części debaty sejmowej. Zapewne w obradach w dniu 16 maja wzięła udział zbiorowość parlamentarna o zbliżonej strukturze politycznej głosujących parlamentarzystów do tej, która uczestniczyła w uchwalaniu pierwszej części prawa o Sejmie. Jednomyślne przyjęcie ustawy bezskutecznie próbował zablokować, odwołując się do potrzeby dalszej deliberacji, Jan Zieliński, poseł zakroczymski ${ }^{43}$, znany $z$ poglądów opozycyjnych ${ }^{44}$. Protestos. 388.

38 Ignacy Potocki do S.S. Potockiego, Warszawa 13 V 1791, BCz, rkps 3473,

39 Stanisław August do F. Bukatego, 14 V 1791, [w:] Ostatnie lata..., s. 189190.

40 Ibidem, s. 190.

41 Gazeta pisana, z Warszawy, 25 V 1791, BK, k. 43.

42 Druga część projektu o Sejmie wniesiona została pod obrady Izby na sesji 13 maja. W wyniku przeprowadzonej dyskusji Deputacja uzyskała czas, aby zając się „poprawa reszty projektu o Sejmie”, jak to sformułowano w diariuszu. Por. Dziennik Czynności Sejmu... 1791, sesja z 13 V.

43 Ibidem, sesja z $16 \mathrm{~V}$.

44 J. D i h m, op. cit., s. 17. 
wał przeciwko jednomyślnemu przyjęciu ustawy Antoni Godlewski, poseł nurski, twierdząc, iż: „nie zgadzał się na przejście tego projektu"45. Ostatecznie jednak wycofał swój sprzeciw i ustawa przyjęta została jednomyślnie ${ }^{46}$.

Takie zakończenie debaty z 16 maja było, jak się wydaje, prosta konsekwencją wielce niekorzystnego dla opozycji głosowania tajnego na sesji z 12 maja. Można przypuszczać, że do przyjęcia zasady jednomyślności skłoniła opozycje po prostu presja konstytucjonistów pragnących uniknąć żmudnej procedury głosowania parlamentarnego $\mathrm{w}$ warunkach, gdy traciło ono sens $z$ uwagi na ujawnioną słabość ugrupowania malkontenckiego. Niewykluczone jednak, że sytuacja ta wydawała się w miarę korzystna w ocenie samych opozycjonistów. Malkontenci, dążąc ze względów politycznych do storpedowania pokonstytucyjnych wysiłków ustawodawczych obozu reformy, zdawali sobie jednocześnie sprawę, że nie maja żadnych szans na skuteczne przeciwstawienie się przyjęciu nowego prawa sejmowego. W tej sytuacji, jak można przypuszczać, nie chcac ujawniać wobec opinii publicznej ogromnej przewagi obozu konstytucyjnego, a tym samym unaoczniać własnej słabości, zdecydowali się na zmianę taktyki postępowania parlamentarnego, odwołując się do zasady jednomyślności. Opozycja zainteresowana była pomniejszaniem sukcesu zwolenników Ustawy Rzadowej, tuszowaniem pokonstytucyjnego tryumfalizmu i, być może, skłonna była do tego dażyć właśnie pod osłona zasady jednomyślności. Poza tym należy mieć na uwadze fakt, iż warstwa merytoryczna ustawy o Sejmie mogła, w gruncie rzeczy, zaspokajać jej wyobrażenia na temat republikańskich rozwiazań ustrojowych.

Rzecz znamienna, że w późniejszym okresie przywódcy obozu konstytucyjnego, przebywajacy na emigracji autorzy pracy o Konstytucji 3 maja, nie chcieli uznać ustawy o Sejmie za swoje dzieło. Rozgoryczeni klęska, poszukując jej winnych, wskazywali na opozycje polityczna: „stronników moskiewskich nowa, bo konstytucyjną barwa przybranych" 47 , jako tych, którzy rzekomo zainspirowali

45 Dziennik Czynności Sejmu... 1791, sesja z 16 V. W nieco innej wersji sprzeciw A. Godlewskiego podaje Diariusz Sejmu Wielkiego, sesja z 16 V 1791, AGAD, ASC nr 19, k. 200v-201. A. Godlewski nie brał udziału w głosowaniu jawnym z 12 V. Por. Protokół głosowań z 12 V 1791 r., AGAD, ASC nr 19, k. 160.

46 Dziennik Czynności Sejmu... 1791, sesja z 16 V.

47 O ustanowieniu i upadku Konstytucyi Polskiej 3go Maia 1791, cz. II, Metz [właściwie: Kraków] 1793, s. 15. O propagandowym charakterze cytowanej pracy por. A. Z a hor ski, Poczatki nowoczesnej propagandy politycznej $w$ Polsce: O usta- 
ustawę sejmowa, a ta winna być miała zasadniczej dekompozycji ustroju trzeciomajowego. Pisali więc o stronnikach moskiewskich, iż: „psuli, ile mogli, w szczególnych projektach, a niby do zasad konstytucyi stosownych, treść i samę konstytucyi istotę. Oczywistym było tego dowodem niesforne prawo o sejmach, wyłudzone naprzód w deputacyi, a potem na sejmie, od Kossakowskiego biskupa i kasztelana trockiego Platera"48. Kontynuujac swoje rozważania, stwierdzali: „Nie udał się zakrój Kossakowskiego i Platera, psucia w szczególnych projektach ogólnych konstytucyi prawideł. Opis tylko sejmu skażonym został nieczystym ich tchnieniem"49. A więc, jak ujmowali to autorzy przywoływanej pracy, przywódcy opozycyjni $z$ biskupem inflanckim Józefem Kossakowskim i kasztelanem trockim Kazimierzem Konstantym Platerem na czele, wyprowadzili na manowce cały skład prokonstytucyjnie zorientowanego Sejmu! Stwierdzenie wyjątkowo mało przekonujące ${ }^{50}$.

Oczywiście, rola jaka odegrał w pracach Deputacji biskup Józef Kossakowski czeka jeszcze na opracowanie. Ustawa sejmowa powstawała jednak $z$ inicjatywy konstytucjonistów i ich była przede wszystkim dziełem ${ }^{51}$. Można tu zauważyć, że sam biskup Józef Kossakowski, jako przewodniczący Deputacji Konstytucyjnej, odnosił się krytycznie do nowej ustawy sejmowej, pisząc: „Nie poj-

nowieniu i upadku Konstytucyi polskiej 3-go Maia, [w:] Kultura polska a kultura europejska. Prace ofiarowane Januszowi Tazbirowi $w$ sześćdziesiąta rocznicę urodzin, Warszawa 1987, s. 99-108.

48 O ustanowieniu i upadku Konstytucyi..., cz. II, s. 15-16. Biskup J. Kossakowski nie wziął udziału w głosowaniu jawnym, a kasztelan K.K. Plater opowiedział się po stronie prawa sejmowego. Por. Protokół głosowań z 12 V 1791, AGAD, ASC nr 19, k. 157 i 158. Pomimo iż Deklaracja Stanów Zgromadzonych zakazywała „przewrotnego” tłumaczenia Ustawy Rzadowej (Deklaracya stanów zgromadzonych, [w:] Vol. leg., t. IX, s. 226) nie podjęto przecież żadnych prób ewentualnego zaskarżenia ustawy sejmowej czy poszczególnych jej zapisów, jako stanowiących ewentualny przejaw „przewrotności” jej rozumienia!

49 O ustanowieniu i upadku Konstytucyi..., cz. II, s. 18-19.

50 Zaprezentowana przez emigracyjnych przywódców narodu wersja uchwalenia ustawy o Sejmie budzi zdumienie, praca ich autorstwa bowiem, o której tu mowa, chociaż posiadała charakter polityczno-propagandowy, to jednak na ogól trafnie, $z$ pewna doza prokonstytucyjnej tendencyjności, oddawała atmosferę zarówno obrad sejmowych, jak i te panujaca na prowincji szlacheckiej. W tym jednak przypadku w sposób drastyczny rozmijali się autorzy przywoływanej pracy $z$ właściwą oceną rzeczywistości.

51 W. S z c zy gi i ls ki, Rozważania na temat Sejmu Wielkiego (w 220. rocznice inauguracji obrad), „Przegląd Nauk Historycznych” 2008, R. VII, nr 2, s. 49$50 \mathrm{i} \mathrm{n.}$ 
muje jakim zapałem i jaka uwaga w przeszłym projekcie Sejmu i zamienionym już w prawo konstytucyjne (według teraźniejszego stylu) umieszczono warunek na ministrów [...] Co rozumieją niektórzy być prerogatywą narodowa, w moim widzeniu uważam ja prerogatywą tronu"52. Rzecz szła oczywiście o możliwość odwoływania ministrów przez Sejm i desygnowania nowych kandydatów przez króla ${ }^{53}$. Podobnie krytycznie, w związku z powyższym postanowieniem, oceniał ustawę o Sejmie, zdeklarowany opozycjonista Ignacy Moszczeński, poseł bracławski54. Relacja biskupa Józefa Kossakowskiego daje świadectwo temu, iż nowe prawo sejmowe zawdzięczało swoje istnienie dużemu zaangażowaniu parlamentarzystów w przeforsowanie określonych zapisów, których on, jako przewodniczacy Deputacji Konstytucyjnej, po prostu nie aprobował. Przeciwnicy Ustawy Rzadowej wyraźnie wskazywali komu ustawa o Sejmie zawdzięcza swoje powstanie. Pokonstytycyjne ustawodawstwo jawiło się bowiem zdeklarowanym opozycjonistom, jako dalszy ciag wydarzeń „rewolucyjnych”, zapoczątkowanych sesja trzeciomajowa. Po uchwaleniu prawa o Sejmie, pisano: „Malkontenci sarkają, mówią, iż rewolucyja jeszcze nie ustała, iż to, co się dzieje jeszcze pod rewolucyja się dzieje"55. W świadomości opozycjonistów pozostawała ustawa sejmowa znaczącym osiagnięciem zwolenników trzeciomajowej rzeczywistości. Jawiła się jako ważne ogniwo w paśmie zaplanowanych przez konstytucjonistów sukcesów politycznych. W końcu maja pisano: „W pośród tych zamachów (podkr. - W.S.), Izba postępuje w swych czynnościach. Wkrótce materyja o Sejmie będzie utarta, po czym pójdą do urządzenia Straży"56.

Stanisław Małachowski tak mówił na sesji w dniu 17 maja 1791 r. o wysiłkach legislacyjnych parlamentarzystów, zwieńczonych uchwaleniem prawa o Sejmie: „Wczorajsza sesyja [...] pamiętna będzie przez zadecydowanie jednomyślnościa prawa o sejmach”.

52 Józef Kossakowski do S.S. Potockiego, Warszawa 17 V 1791, BCz, rkps 3473, s. 401.

53 Por. Z. S z c z ą s k a, op. cit., s. 67-69.

54 Ignacy Moszczeński do S.S. Potockiego, Warszawa 18 V 1791, BCz, rkps 3473, s. 403.

55 Józef Rozan do S.S. Potockiego, Warszawa 18 V 1791, ibidem, s. 503.

56 Józef Rozan do S.S. Potockiego, Warszawa 25 V 1791, ibidem, s. 497. Zapis autora listu o przyszłościowym „utarciu” ustawy sejmowej (choć uchwalona została przecież 12 i 16 maja) wynikał $z$ oczekiwania na jej oblatowanie, które nastąpiło dopiero 28 maja (zapewne w wyniku żmudnych prac redakcyjnych). 
Wpisywała się owa ustawa, jak można wnosić z kontekstu wystapienia marszałka sejmowego, w nurt dokonań reformatorskich dzięki którym, jak mówił: „wzrosła do tego stanu Ojczyzna, iż się może w rzędzie $z$ największemi państwami w Europie policzeć"57. Pozytywnie ocenial nowe prawo sejmowe w szerszym pakiecie postanowień Sejmu, Julian Ursyn Niemcewicz, piszac: „Spieszniejszym [...] krokiem szły od zaprzysiężenia konstytucji czyny sejmowe [...] Opisanie sejmów, Straży, Komisji Policji [...] słowem, zaniedbania tylu wieków naprawione w tym jednym sejmie"58. Król, z oczywista doza aprobaty, pisał ogólnie o ustawodawstwie okołokonstytycyjnym: „Od 3-go maja sejm nie przestał urządzać wielu szczegółów następstw postanowienia w tym dniu powziętego"59.

Ustawa o Sejmie spotkała się z życzliwym przyjęciem opinii publicznej. Pisano: „Po uchwaleniu sposobów sejmowania już Konstytucyja nowego rządu stanęła na dobrym fundamencie"60. Mówiono wprost, iż: „wszechwładztwo narodu zgromadzonego na sejmie" stawało się gwarantem społecznej akceptacji Ustawy Rzacowej61. Umacniając suwerenność Sejmu sprzyjała ustawa procesowi jej unarodowienia. Konstytucja 3 maja zakorzeniała się w świadomości społecznej.

Podsumowując dotychczasowe rozważania można powiedzieć, że była ustawa sejmowa w $75 \%$ oddanych na nia głosów dziełem zdeklarowanych zwolenników Konstytucji majowej. Co więcej, analiza protokołu głosowania jawnego wskazuje, że było owo prawo sejmowe, w swej zasadniczej kanwie decyzyjnej, dziełem dosłownie tych samych parlamentarzystów, którzy na sesji trzeciomajowej przesądzili o przyjęciu Ustawy Rządowej. Przebieg sesji w dniu 12 maja daje świadectwo temu, że opozycja trzeciomajowa odniosła się do ustawy o Sejmie negatywnie. I tę konstatację odnieść by chyba należało również do sesji z 16 maja. Wprawdzie w końcowym tekście tejże ustawy, w wyniku jednogłośnego jej uchwalenia,

57 Dziennik Czynności Sejmu... 1791, sesja z 17 V.

58 J.U. N i e m c e w i c z, op. cit., t. I, s. 345-346.

59 Stanisław August do Maurycego Glayre'a, 21 VI 1791, [w:] Stanisław Poniatowski i Maurycy Glayre. Korespondencya dotyczaca rozbiorów Polski, wyd. E. Mottaz, przekł. J. z Chmielowskich Baranowska, przejrzał S. Krzemiński, cz. II, Warszawa [1901], s. 118.

60 Gazeta pisana $z$ Warszawy, 31 V 1791, Biblioteka Raczyńskich w Poznaniu, 1441/18, nr 46, k. 634v.

61 Pamiętniki Michała Ogińskiego o Polsce i Polakach od r. 1788 aż do końca r. 1815, t. I, Poznań 1870, s. 91. 
tkwia również głosy opozycji trzeciomajowej, to jednak jej rolę widzieć można w biernym jedynie przypisaniu się do ustawy, lansowanej przez konstytucjonistów, w sytuacji gdy okazało się, że malkontenci nie mają najmniejszych szans na storpedowanie nowego prawa sejmowego. Pewna złożoność sytuacji polegała jednak na tym, iż charakter ustawy, akcentującej suwerenność Sejmu, sytuował ja w kanonie wartości republikańskich, które rzeczywiście mogły być bliskie wielu opozycjonistom.

Nawiązując do zaprezentowanego na wstępie niniejszych rozważań sformułowania Władysława Smoleńskiego, można powiedzieć, że analityczne badania dotyczace sesji z 12 maja w pełni potwierdzają obserwację autora o republikańskich skłonnościach zbiorowości parlamentarnej zaangażowanej w proces uchwalania ustawy sejmowej. Uwolnić by jednak należało owo sformułowanie od nazbyt pejoratywnych skojarzeń, jakie zasugerował autor, a stawianie przysłowiowego znaku równości, jak czyni to Władysław Smoleński, pomiędzy zapatrywaniami republikańskimi zwolenników Ustawy Rządowej i zagorzałych opozycjonistów, wydaje się zabiegiem wielce wątpliwym. Dzieła, o którym mowa, dokonywał najbardziej zaangażowany $\mathrm{w}$ proces reformy odłam zbiorowości szlacheckiej, który w procesie kształtowania nowego modelu państwa uwalniał przecież republikanizm od takich jego skrajności, jak wolna elekcja, wiążacy charakter instrukcji czy dozorcze jedynie uprawnienia władzy rządowej typu Straży. I o tym należy pamiętać. Oczywiście, nowe prawo kształtowało swoiście pojmowany Sejm udzielny 62 z wszystkimi wynikającymi stąd konsekwencjami. Ale podnosząc ten problem należy jednak mieć na uwadze fakt, jak wielkie zmiany zachodziły w zapatrywaniach szlacheckich na rolę Sejmu w toku toczacych się prac parlamentarnych. Gdy jeszcze w początkach obrad, u schyłku 1788 r., rzecz szła o zastapienie Rady Nieustającej Sejmem nieustającym, rządzącym, a więc łączącym władze ustawodawcza $z$ wykonawcza, to omawiana ustawa z 12 i 16 maja 1791 r. wpisywała już Sejm w monteskiuszowska zasadę podzielności władzy, wprawdzie spaczona poprzez zwichnięcie wzajemnej między władzami równowagi, ale przecież wyodrębniająca formację władz wykonawczych $z$ decyzyjnymi uprawnieniami organu rządowego typu Straży. Być może należało by mówić, iż nowe prawo o Sejmie osłabiało co nieco, tak bliska Stanisławowi Augustowi, wizję państwa monarchii konstytucyjnej,

62 Do pojęcia tego odwołuje się B. Le ś n o d or s ki, op. cit., s. 307. 
kładąc podwaliny pod bliższy ogółowi szlacheckiemu model państwa w postaci monarchii parlamentarnej czy konstytucyjnoparlamentarnej, $z$ wiodąca $w$ nim rolą Sejmu ${ }^{63}$.

63 E. Ros two row ski, Republikanizm polski $i$ anglosaski $w$ XVIII wieku, „Miesięcznik Literacki” 1976, R. XI, nr 8, s. 99, 103. 